\title{
Protection of Telomeres Protein 1
}

National Cancer Institute

\section{Source}

National Cancer Institute. Protection of Telomeres Protein 1. NCI Thesaurus. Code C107657.

Protection of telomeres protein 1 ( $634 \mathrm{aa}, \sim 71 \mathrm{kDa}$ ) is encoded by the human POT 1 gene. This protein plays a role in telomere maintenance. 